external temperature for days. The author saw preparations still pulsating strong $y$ and regularly on the fourth day. (The liquid, in that case, must be often renewed.) These rhytbmic contractions of a voluntary striped muscle, indicating chemical stimulus, awaken special interest, through their similarity to the long-known contractions of the apex of the heart, separated and without ganglia, in blood-serum. The heart-muscles, it is known, are also striped.

The Gorilla AND the Chimpanzee.-Mr. H. von Koppenfels, who is now engaged in explorations in the Gaboon district of Western Africa, in a letter published in the last number of the American Naturalist, states that he has good evidence of the existence of crosses between the male gorilla and the female chimpanzee. "This," he says, "settles all the questions about the gorilla, chimpanzee, Kooloo-Kamba, N'schigo, M'bouvé, the Sokos, Baboots, \&c." Herr v. Koppenfels observes that the "French savants seem to have a special predilection for creating new species from variations in the form of the skull, such as often occur in this group of animals. There is but one district which forms the range of the gorilla, and this is situated in the western part of Equatorial Africa, and here it exhibits no varieties, while the chimpanzee is found all over Tropical Africa, and naturally exhibits considerable variation. The chimpanzee of Northern Guinea differs essentially from that of the southern portion of the same country, and, according to Livingstone, the 'Soko' differs from both, but is still a chimpanzee. Du Chaillu's Kooloo-Kamba, N'schigo, and M'bouvé are not distinct species, and this traveller, who is certainly a man of merit, but is too credulous, has been imposed upon by the mendacity of the natives, which beggars description. The names N'schigo, M'bouvé, Koola, Baboo, Soko, Quia, and Kooloo-Kamba are only different designations of the chimpanzee by different tribes. The mongrel progeny of the male gorilla and female chimpanzee di covered by me is found but in individual cases, and as such deserves no special name."

Salivary Globules.-Prof. Stricker of Vienna, by examina tion of salivary globules under high-power lenses (obj. No. $X$. of Krafft and Seivert), has obtained the following results :He cannot accept the supposition of a so-called Brownian (molecular) movement in salivary corpuscles. He has found the globules to consist of a complete, distinctly visible network. The granules, which have been seen under low powers of the microscope, appear on close inspection and carefully focussing to be thickened points of intersection of the threads forming the reticulum. There is a permanent fluctuation of the threads during the life of the corpuscle. By the action of concentrated salt-solutions the fluctuation ceases gradually and the reticular arrangement disappears.

Fish Mortality in the Gulf of Mexico.-From time to time since 1844 a widespread destruction of all sorts of marine creatures has occurred along certain well-marked-out tracts in the Gulf of Mexico. In 1854 the fishes suffered all along the southern shore; in 1878 there was again an excessive mortality in 1879 the plague again appeared; while in 1880 , we learn from the recently-published report of Inspector Ingersall to Prof. S. $\mathrm{F}$. Baird, it has been very intense. The poisoned waters occur in streaks or patches, sometimes near to one another, at other times many yards apart. These seem to drift with the flow of the tide, and ultimatcly become diluted. The most probable solution of this strange phenomenon is to suppose that eruptions of noxious volcanic gases arise through the bottom of the sea; certain it is that the marine life on the sea-bottom suffers first. Sponges, sea-anemones, mollusks, and the ground fish die in mass, and apparently at once. Upwards the deadly pestilence mounts, and the small fish swimming at or near the surface are killed by thousands, and float lifeless on the water. The large surface fish would seem to escape, and rarely is a mullet to be found destroyed. Fishing in such districts has to be abandoned, even although in the pure streaks the fish abounded, for should a smack fill its well with the results of a successful catch it had to run the gauntlet of the broad patches of the poisoned waters, and if any of these were encountered, and entered the well, a few moments would suffice to bring about the death of every fish in the cargo. The keeper of the Egmont Lighthouse writes on February 21 in this year: "As the tide came in on October 17 , 1880 , there were thousands of small fish floating on the water, most of them quite dead. The next day the fish were dying al along the shore; between October 25 and November ro the stench was so horrible that it was impossible to go on the beach.
Sending my family to Manatee, the assistant-keeper and myself shut ourselves up in our rooms, and kept tar, coffee, \&c., burning day and night in order to stand it. The peculiar smell was like bilge-water. The fish I noticed dying acted as if crazy, darting around in every direction, then giving up and floating ashore. After a very heavy gale from the south-west the bad and good waters got mixed up, and soon all the fish caught were fat and nice." As the cause of this strange phenomenon is still problematical, some discarding the idea of the evolution of subter. ranean gases, believing it to be the result of a poisoning of the waters by an excess of rain-water discharged into the Gulf by the rivers, others that it is owing to the water being saturated with the tannin derived from decomposing roots and stems of palmetto, sumach, oak, \&c., it would seem highly desirable that Prof. Baird should institute a series of observations as to the chemical constituents at different times of the waters of these districts.

On the Nectar-secteting Glands in Species of MelamPYRUM. - The cow. wheats are a familiar group of plants, of which several species are to be found native. E. Ráthay, while investing the subject of the secretion of sugar by plants, was attracted by the appearance of swarms of ants evidently collecting some sweet material from the little dark puncta on the bracts of Melampyrum arvense (purple cow.whent). These puncta, even under a handlens, are seen to be little round disk-shaped bodies, which proved to secrete a sugary secretion for which the ants came. In a memoir on this subject these gland-like disks are de cribed and figured as they occur in $M$. arvense, $M$. nemorosum, $M$. pratense, and $M$. barbatum. These bodies have long since been observed by the systematic botanists; they form part of the trichomic development of the epidermal system of the bracts, and may be described as consisting of a short foot-cell, attached to the centre of which is a circular disk. This latter is composed of a single layer of seven-sided cells. According to their function these structures in the species of Melampyrum mentioned belong to the epidermal glands of De Barry, since they secrete upon the upper side of their disk, between the cuticle and cell-membranes of the seven-sided cells, a liquid which, through the bursting of the cuticle, gets out, and is sought by the ants and eaten. The secreted fluid contains at least 2 per cent. of a kind of sugar which is not reducible by oxide of copper. The history of the development of these structures is practically the same as that of other similar formations. The purpose which they serve to the Melampyrum would seem neither to be explained by the hypothesis of Belt and Delpino as to the meaning of the extra floral nectaries, nor according to the hypothesis of Kerner concerning the same. Rathay further adds that the moistne:s which almost always appears over these structures is quickly, on re. moval, renewed; that this moistness increases so much as to form drops when the plants are protected fron the approach of ants, \&c.; and that this drop-formation is repeated several times if the drops are from time to time removed (Vienna Academy Proceedings, vol. Ixxxi. 1880).

\section{CHEMICAL NOTES}

M. RAOULT states in Compt. rend. that the oxides of barium. strontium, and calcium rapidly absorb carbon dioxide at a high teinperature : much heat is evolved in the reaction, the tempera. ture of the mass in the case of barium oxide being as high as $\mathbf{2} 200^{\circ}$, according to a pyrometric determination.

MM. CAIllfieT AND HAUTEFEuILle have determined the densities of liquid oxygen, nitrogen, and hydirogen (Compt. rend.) by liquefying these gases mixed with carbonic anhydride and with nitrous oxide, and basing their calculations on the assumption that the mixed liquids are without action on one another. The density of liquid oxygen at $-23^{\circ}$ (pressure $=300$ atmos.) was found to be 0.89 from experiments with carbonic anhydride, and $0^{\circ} 94$ from experiments with nitrous oxide: at $0^{\circ}$ the numbers obtained were 0.58 and 0.65 respectively. Liquid nitrogen at $-23^{\circ}$ gave numbers corresponding with the density 0.44 , while at $0^{\circ}$ the density was $0^{\circ} 37$. The density of liquid hydrogen was 0033 at $-23^{\circ}$, and 0.025 at $0^{\circ}$. Dividing the atomic weights of the three elements by the densities at $-23^{\circ}$, the atomic volume of oxygen is found to be 17 , of nitrogen $3 I^{\circ} 8$, and of hydrogen 30.3 .

HERR O. Löw describes experiments with fluorspar from wolsendorf (Berliner Berichte), which seem to show that the liquid contained in the cavities of this mineral consists of free 
fluorine. When the mineral is broken up, a strong chlorine-like odour is perceptible; when heated with sulphur, an odour resembling that of sulphur chloride is evolved; the liquid in the mineral decomposes sodium chloride and iodide, with formation of chlorine and iodine respectively. On addition of dilute potash it yields a solution which instantly decolorises indigo solution. When the mineral is moistened with ammonia water, powdered, the liquid filtered off, neutralised with sodium carbonate and evaporated, a residue is obtained which, on addition of sulphuric acid, evolves hydrofluoric acid. Herr Löw thinks that the fluorine is produced by dissociation of cerium fluoride in the mineral.

THE application of potassium oxalate as a precipitant for many heavy metals, both in qualitative and quantitative analysis, is described by Herr von Reis in the Berichte of the German Chemical Society; the quantitative results obtained are very accurate.

THE reaction of bleaching powder on alcohol, which results in the formation of chloroform, is not thoroughly understood. $M$. Béchamp details experiments (Annales Chim. et Phys.), according to which no oxygen is evolved during the change, but only after the primary change is complete, and a secondary change begins when the reacting bodies have acquired a high temperature. The formation of chloroform is represented by $\mathbf{M}$. Béchamp by the following equation, $2 \mathrm{C}_{2} \mathrm{H}_{6} \mathrm{O}+{ }_{4} \mathrm{Ca}(\mathrm{OCl})_{2}=\mathrm{CaCl}_{2}+2 \mathrm{H}_{2} \mathrm{O}$ $+2 \mathrm{Ca}(\mathrm{OH})_{2}+\left(\mathrm{HCO}_{2}\right)_{2} \mathrm{Ca}+2 \mathrm{CHCl}_{3}$.

In Annali di Chimica Signor Chiappe states that he has found spots of minium $\left(\mathrm{Pb}_{3} \mathrm{O}_{4}\right)$ on various marble monuments, on parts of which bands of lead have been fastened. He supposes that by the action of the air and rain lead carbonate is produced, this is absorbed by the marble, and when exposed in places to the sun's rays it is decomposed with production of minium.

A VARIETY of coal, said to be the most highly-carbonised member of the coal series hitherto described, has been found near Schunga, on the western shores of Lake Onega (Fahrbuch für Mineralogie) ; it contains about 91 per cent. carbon, 7 or 8 per cent. water, and I per cent. ash. This coal is extremely hard and dense, has an adamantine lustre, is a good conductor of electricity, and has a high specific heat (0.1922). Although containing as much carbon as the best graphites from Ceylon, it is not a true graphite, inasmuch as it is not oxidised by potassium chlorate and nitric acid, but behaves towards those reagents like an amorphous coal.

FEDER AND VOIT have carefully repeated the experiments of Hallervorden on the effect of feeding with ammonium carbonate (Zeitschrift fiir Biologie). The results confirm the statement of the last-named author, that in dogs ammonium carbonate is converted into urea, and also show that ammonium acetate undergoes a similar change.

IT has been asserted that the employment of sodium nitrate in manures facilitates the solution and removal from the soil of plant-foods: Herr Fiedler has recently examined this subject experimentally, and he thinks himself justified in concluding that nitrates do not dissolve out any considerable quantities of plant-foods from the soil ; that, within certain limits, absorption of phosphoric acid is favoured and absorption of potash slightly impeded by sodium nitrate; and that the same salt exerts a solvent action on dibasic phosphates of calcium, iron, and aluminium, but not on the tribasic phosphates of these metals.

\section{GEOGRAPHICAL NOTES}

AT the meeting of the Geographical Society on Monday last, Lieut. Col. C. E. Stewart, of the Bengal Staff Corps, read some portions of a paper which he had prepared on the country of the Tekke Turkomans and the Tejend and Murghab Rivers. Col. Stewart, it may be remembered, is one of the officers who was accused, in a recent official despatch from St. Petersburg, of "haunting the oases" in the Turkoman country: this paper was consequently looked forward to with much interest. He left Constantinople in April of last year, and proceeded in the first instance to Ispahan, where he spent two months and a half in the Armenian quarter of Julfa, making preparations for his journey, as he had determined to travel in the disguise of an Armenian horse dealer. On September 30 he went to Ardakan, where he assumed his disguise, and travelled in a north-easterly direction along the edge of the salt desert to Meshed, afterwards crossing the mountains to Mahomedabad. The account of this part of his journey, with its numerous adventures, Col. Stewart was unfortunately obliged to omit, owing to the length of his paper. Deregez, in which Mahomedabad is situated, is in the most northern part of North-east Persia beyond the mountains, and is some sixty-five miles long and forty broad; as it projects into the Turkoman country, it is a most favourable position for collecting information respecting the neighbouring country to the Caspian on one side, and to Merv on the other. Col. Stewart made Mohamedabad his head-quarters from November 25 to January I 5 , and during this time moved about in Deregez, but never crossing the Persian frontier, and obtained much interesting information by diligent inquiry among the Persian officials and the Turkomans whom he met. This particularly applies to the Merv district-for he denies the existence of a town of Mervand the Murghab River. Col. Stewart also explained very clearly the Russian line of advance, and the present and future position of the railway question. It may be interesting to add that his disguise was completely successful, and entirely deceived even the Persian servant of Mr. O'Donovan, the enterprising correspondent of the Daily News, who is now detained in the Merv district.

THE fiftieth and last volume of the Geographical Society's fournal is chiefly occupied with Mr. C. R. Markham's history of the fifty years' work of the Society, which is at once valuable and entertaining. In it will be found detailed the actual circumstances attending the establishment of the Society, about which some misapprehension has hitherto prevailed. This took place in July, 1830 , and the Society is therefore now fifty-one years old : after passing through many vicissitudes, which at one time threatened its very existence, it now numbers 3394 ordinary Fellows, and is the largest and wealthiest institution of the kind in the world. Mr. Markham, we may add, has been able to reproduce its first list of 460 Fellows, dated August 4, 1830. In a voluminous appendix, equal in length to the history, he furnishes complete lists of officers from the commencement, references to obituary notices of distinguished men, lists of explorers and geographers who have received medals, grants in aid of their work, \&c., and of the papers and maps published by the Society. Lastly there is some interesting informa. tion respecting the Hakluyt Society. The few remaining page of the volume contain notes on two maps of the Andaman Islands by Mr. E. H. Man and Lieut. R. C. Temple, and on the history and origin of the word "Typhoon," by Dr. F. Hirth, tables of altitudes in East Central Africa computed from $3 \mathbf{I} 7$ observations taken by Mr. Joseph Thomson during his recent East African expedition, and a narrative of a journey overland from Amoy to Hankow by Mr. E. F. Creagh. From a brief prefa. tory notice we learn that the issue of the fournal is to be dis continued, and that in future "elaborate papers of more than ordinary length and great value" will be published as supplements to the monthly Proceedings.

From the Colonies and India's Queensland notes we learn that $\mathrm{Mr}$. Watson, in command of the Transcontinental Railway Survey, had crossed the Worna and Workingham Creeks in safety, and reported the soil magnificent and the grass splendid. The floods had however "sadly hampered the expedition," and this fully bears out the remarks made in NATURE, vol. xxiv. p. II4, as to the route for the line laid down on the Government map. It has lately been announced that General Fielding and Mr. J. Robinson, C.E., have gone out to make what is presumably an independent survey for a line, and we hope they may be able to find a more suitable route. The arrival of Mr. Watson's party at Point Parker, on the southern shore of the Gulf of Carpentaria, has since been announced by telegraph.

THE new Bulletin of the Bordeaux Society of Commercial Geography contains an address recently delivered before it by Capt. Gallieni, on his expedition, chiefly for surveying purposes, from the Senegal to the Niger. It is accompanied by a sketchmap of the region, on which the routes of the expedition are laid down.

PROF. ROWLAND'S NEW THEORY OF MAGNETIC ACTION

PROF. ROWLAND has lately published in the American Journal of Mathematics (vol. ii., No. 4; vol. iii., Nos. I and 2) a series of papers on "The General Equations of Elec tromagnetic Action with application to a New Theory of Mag- 